\title{
Viability and Vigour of Different Maize (Zea mays L.) Inbred Lines Treated with Neonicotinoids
}

\author{
Gordana Tamindžić* · Zorica Nikolić · Dragana Milošević · Maja Ignjatov
}

Institute of Field and Vegetable Crops, Maksima Gorkog 30, 21000 Novi Sad

\begin{abstract}
Summary: The aim of this study was to examine the effects of different neonicotinoid seed treatments on viability and vigour of maize (Zea mays L.) inbred lines. The trial included three maize inbred lines (207 x 312/5 DNS, 7-1 NS, and $312 / 5$ DNS) treated with recommended doses of three commercial formulations of systemic insecticides (Poncho 600-FS, Gaucho 600-FS, and Cruiser 350-FS). Generally, formulation Gaucho 600-FS can be considered the most harmful regarding the impact on the reduction of germination in all tested maize inbred lines. A significant reduction of germination in maize inbred line 7-1 NS was observed after seed treatment with Cruiser 350-FS, using the standard germination test and cold test. A significant increase in seedlings root and shoot growth of maize inbred line 312/5 DNS treated with Poncho 600-FS and Cruiser 350-FS was noted using the cold test.

Key words: maize, maize inbred line, neonicotinoids, vigour, viability, standard germination test, vigour tests
\end{abstract}

\section{Introduction}

Maize (Zea mays L.) production in Serbia is threatened by a number of pests during the entire growing season (fam. Elateridae, Melolontha melolontha L., Diabrotica virgifera virgifera L., Euxoa temera Hb., Scotia ipsilon Nufn., Scotia segetum Schiff., Tanymecus dilaticollis Gyll., Phyllotreta vittula Redt.) (Sekulić et al., 2005). Seed treatment ensures that the insecticide is in the vicinity of the future plant, where it is the most needed and shows the highest level of expression (Marjanović-Jeromela et al., 2008). Surely, seed protection against pathogens and pests must not be at the expense of seed quality (Abba \& Lovato, 1999; Aveling et al., 2012).

Neonicotinoids are the newest among five major classes of insecticides (Tomizawa \& Casida, 2011). Numerous studies indicate positive effects of neonicotinoids, such as activation of gene expression, which leads to higher water absorption and ion transport (Castro et al., 2009), or a higher enzymatic activity which increases primary and secondary metabolism, at the seed level or at the plant one(Castro et al., 2008; Almeida et al., 2013).

The basis of modern agricultural production is high -quality and vigorous seeds. Seed vigour is the sum of

\section{Corresponding author:}

gordana.tamindzic@ifvcns.ns.ac.rs

Acknowledgement:

This study is a part of the project TR 31073 (Improvement of maize and sorghum production under stress) financed by the Ministry of Education, Science, and Technological Development of the Republic of Serbia. properties which determine the activity and performance of the seed lots of acceptable germination in a wide range of environments (ISTA, 2014). The term seed viability is generally used to describe the physiological characteristics of seeds which express its ability to germinate rapidly under favourable environmental conditions, as has been well documented in literature (Vujaković et al., 2011b; Milošević et al., 2010). Testing seed vigour and viability in laboratory is significant, given that the results of vigour tests are often in better relation with the results of field emergence in different environmental conditions, than those obtained by a standard germination test (Vujaković et al., 2011a). Vigour tests provide more detailed information about seed physiological quality of maize inbred lines, with insight into seed storage potential and an estimation of seed performance in field conditions. Since the seeds are a biological material, they can be sensitive to insecticidal formulations, especially considering the large number of varieties and inbred lines.

Most studies of neonicotinoids have focused on their effect on germination, plant growth, and yield of many crops, as well as the phytotoxic effects and efficacy of neonicotinoid seed treatments for pest management (Cataneo et al., 2010; Stevens et al., 2008; Cox et al., 2007; Koch et al., 2005; Kuhar et al., 2002). On the other hand, there is insufficient information about the effects of neonicotinoid seed treatments on seed viability and vigour of maize inbred lines.

The aim of this study was to determine the effect of selected commercial formulations on the seed 
physiological quality of maize inbred lines under optimal laboratory conditions, and provide information on seed vigour of different maize inbred lines treated with the selected insecticidal formulations.

\section{Material and Methods}

Laboratory testing of the effects of formulations Poncho 600-FS, Gaucho 600-FS, and Cruiser 350-FS, on seed viability and vigourin maize inbred lines $207 \mathrm{x}$ 312/5 DNS, 7-1 NS, and 312/5 DNS, was conducted at the Laboratory for Seed Testing, Institute of Field and Vegetable Crops in Novi Sad, Serbia. The selected inbred lines were developed at the Institute of Field and Vegetable Crops, Novi Sad. The tested seeds were produced in the same year. Untreated seeds were taken as controls. Seed samples were treated with commercial formulations Poncho 600-FS (active ingredient clothianidin) in recommended dose of $280 \mathrm{ml} 100 \mathrm{~kg}^{-1}$ seed, Gaucho 600-FS (active ingredient imidacloprid) in recommended dose $600 \mathrm{ml} 100 \mathrm{~kg}^{-1}$ seed, and Cruiser 350FS (active ingredient thiamethoxam) in recommended dose of $900 \mathrm{ml} 100 \mathrm{~kg}^{-1}$ seed before testing.

\section{Standard germination test}

Working sample consisted of 4 x 100 randomly selected seeds. Sterile sand was used as the substrate. Seeds were incubated in the germination chamber at $25{ }^{\circ} \mathrm{C}$ for seven days (ISTA 2014). Seed germination (percentage of normal seedlings) and the percentage of abnormal seedlings were determined seven days after sowing.

\section{Cold test}

Working sample consisted of 4 x 50 randomly selected seeds. Seeds were sown in a mixture of soil and sand in the ratio $3: 1$. The samples were exposed to a low temperature of $7{ }^{\circ} \mathrm{C}$ for seven days, and afterwards placed in the germination chamber at $25^{\circ} \mathrm{C}$ for six days. After this period the germination and the percentage of abnormal seedlings were determined (Hampton \& TeKrony, 1995).

\section{Accelerated ageing test}

Working sample consisted of 4 x 100 randomly selected seeds. The seeds were exposed to a high temperature $\left(42{ }^{\circ} \mathrm{C}\right)$ and high relative humidity $(100 \%)$ for 96 hours. After this period, the seeds were sown in

Table 1. Germination (\%) and abnormal seedlings (\%) of maize inbred line 207 x 312/5 DNS

\begin{tabular}{|c|c|c|c|c|c|c|}
\hline \multirow[b]{3}{*}{ Seed treatment } & \multicolumn{6}{|c|}{ INBRED LINE $207 \times 312 / 5$ DNS } \\
\hline & \multicolumn{3}{|c|}{ Germination of normal seedlings (\%) } & \multicolumn{3}{|c|}{ Abnormal seedlings (\%) } \\
\hline & $\begin{array}{c}\text { Standard } \\
\text { germination } \\
\text { test } \\
\end{array}$ & Cold test & $\begin{array}{l}\text { Accelerated } \\
\text { ageing test }\end{array}$ & $\begin{array}{l}\text { Standard } \\
\text { germination test }\end{array}$ & Cold test & $\begin{array}{c}\text { Accelerated } \\
\text { ageing test }\end{array}$ \\
\hline Control & $97.25 \mathrm{a}$ & $93,50 \mathrm{ab}$ & $93.50 \mathrm{a}$ & $1.75 \mathrm{a}$ & $5.00 \mathrm{ab}$ & $4.00 \mathrm{a}$ \\
\hline Poncho 600-FS & $96.25 \mathrm{a}$ & $90,00 \mathrm{~b}$ & $77.50 \mathrm{c}$ & $2.50 \mathrm{a}$ & $5.50 \mathrm{ab}$ & $0.00 \mathrm{~b}$ \\
\hline Gaucho 600-FS & $90.75 \mathrm{~b}$ & $79.50 \mathrm{c}$ & $84.50 \mathrm{bc}$ & $2.75 \mathrm{a}$ & $11.50 \mathrm{a}$ & $6.50 \mathrm{a}$ \\
\hline Crusier 350-FS & $97.00 \mathrm{a}$ & $98.00 \mathrm{a}$ & $93.00 \mathrm{ab}$ & $1.50 \mathrm{a}$ & $1.00 \mathrm{~b}$ & $5.00 \mathrm{a}$ \\
\hline$F$ values & 22.36 & 10.42 & 7.493 & 0.872 & 4.545 & 4.696 \\
\hline$P$ values & 0.00003 & 0.0012 & 0.0044 & 0.483 & 0.0238 & 0.0216 \\
\hline
\end{tabular}

Average means. Each value with the same letter is at the same level of significance for 95\% interval (Duncan's multiple comparison test $\mathrm{F}$ and $\mathrm{p}$ value)

Table 2. Shoot and root growth (mm) of seedlings of maize inbred line $207 \times 312 / 5$ DNS

\begin{tabular}{|c|c|c|c|c|c|c|}
\hline \multirow[b]{3}{*}{ Seed treatment } & \multicolumn{6}{|c|}{ INBRED LINE $207 \times 312 / 5$ DNS } \\
\hline & \multicolumn{3}{|c|}{ Shoot length (mm) } & \multicolumn{3}{|c|}{ Root length (mm) } \\
\hline & $\begin{array}{c}\text { Standard } \\
\text { germination } \\
\text { test }\end{array}$ & Cold test & $\begin{array}{l}\text { Accelerated } \\
\text { ageing test }\end{array}$ & $\begin{array}{c}\text { Standard } \\
\text { germination } \\
\text { test }\end{array}$ & Cold test & $\begin{array}{l}\text { Accelerated } \\
\text { ageing test }\end{array}$ \\
\hline Control & $139.875 \mathrm{ab}$ & $95.750 \mathrm{ab}$ & $125.625 \mathrm{~b}$ & $124.750 \mathrm{ab}$ & $119.875 \mathrm{a}$ & $136.875 \mathrm{a}$ \\
\hline $\begin{array}{c}\text { Poncho } 600- \\
\text { FS }\end{array}$ & $122.500 \mathrm{~b}$ & $62.250 \mathrm{c}$ & $126.375 \mathrm{~b}$ & $112.500 \mathrm{bc}$ & $88.875 \mathrm{c}$ & $132.000 \mathrm{a}$ \\
\hline $\begin{array}{c}\text { Gaucho } 600- \\
\text { FS }\end{array}$ & $159.125 \mathrm{a}$ & $83.250 \mathrm{~b}$ & $109.250 \mathrm{c}$ & $131.625 \mathrm{a}$ & $102.875 \mathrm{~b}$ & $108.875 \mathrm{~b}$ \\
\hline Crusier 350-FS & $160.625 \mathrm{a}$ & $98.625 \mathrm{a}$ & $138.500 \mathrm{a}$ & $110.375 \mathrm{c}$ & $96.625 \mathrm{bc}$ & $101.000 \mathrm{~b}$ \\
\hline $\mathrm{F}$ values & 7.096 & 15.988 & 13.675 & 5.671 & 20.949 & 9.51 \\
\hline $\mathrm{P}$ values & 0.0053 & 0.0002 & 0.00035 & 0.0118 & 0.00005 & 0.00171 \\
\hline
\end{tabular}

Average means. Each value with the same letter is at the same level of significance for 95\% interval (Duncan's multiple comparison test $\mathrm{F}$ and $\mathrm{p}$ value) 
sterile sand and incubated in the germination chamber at $25^{\circ} \mathrm{C}$ for seven days. The final count of seed germination and the percentage of abnormal seedlings were determined seven days after sowing (Hampton \& TeKrony, 1995).

Determination of seedling growth was conducted four days after sowing. Ten normal seedlings per each replicate were placed at the wetted filter paper. Shoot and root length $(\mathrm{mm})$ were measured seven days after sowing.

The obtained results were processed statistically, using the analysis of variance (One-Way ANOVA) as described by many authors (Hassain et al., 2012; Moore \& Kröger, 2010; Sivparsad et al., 2014).Testing the differences between the treatments by Duncan's multiple range test was conducted using the software Statistica 12 (STATSOFT, Inc., 2015).

\section{Results}

The results obtained in this study showed that maize inbred line 207 x 312/5 DNS had a high germination rate in the standard germination test (Table 1). A significant decrease ingermination was observed in all three tests when the seed samples were treated with imidacloprid. Unfavourable conditions of the accelerated ageing test and treatment with clothianidin led to a significant decrease in germination precentageof inbred line 207 x 312/5 DNS, although the percentage of abnormal seedlings $(0.00 \%)$ was significantly lower $(\mathrm{p}<0.05)$ compared to control.

No significant differences in shoot and root length of seedlings were observed using the standard germination test, and shoot length of seedlings using cold test (Table 2). A significant reduction of shoot $(109.250 \mathrm{~mm})$ and root length $(108.875 \mathrm{~mm})$ of seedlings were observed when treated with imidacloprid using accelerated ageing test. All seed treatments affected root length of seedlings compared to control when using cold test. Seed treatment with thiamethoxam also affected root length $(101.000 \mathrm{~mm})$ of seedlings in all three tests $(\mathrm{p}<0.05)$.

Seed treatment with thiamethoxam led to the decrease in germination in both standard germination test and cold test for the inbred line 7-1 NS (Table 3). No significant differences in germination were observed using the accelerated ageing test $(p>0.05)$. A significantly greater percentage of abnormal seedlings was observed in all

Table 3. Germination (\%) and abnormal seedlings (\%) of maize inbred line 7-1 NS

\begin{tabular}{|c|c|c|c|c|c|c|}
\hline \multirow[b]{3}{*}{ Seed treatment } & \multicolumn{6}{|c|}{ INBRED LINE 7-1 NS } \\
\hline & \multicolumn{3}{|c|}{ Germination of normal seedlings $(\%)$} & \multicolumn{3}{|c|}{ Abnormal seedlings $(\%)$} \\
\hline & $\begin{array}{c}\text { Standard } \\
\text { germination } \\
\text { test }\end{array}$ & Cold test & $\begin{array}{l}\text { Accelerated } \\
\text { ageing test }\end{array}$ & $\begin{array}{c}\text { Standard } \\
\text { germination } \\
\text { test }\end{array}$ & Cold test & $\begin{array}{l}\text { Accelerated } \\
\text { ageing test }\end{array}$ \\
\hline Control & $98.75 \mathrm{a}$ & $97.00 \mathrm{a}$ & $97.00 \mathrm{a}$ & $0.25 \mathrm{~b}$ & $2.00 \mathrm{a}$ & $1.50 \mathrm{a}$ \\
\hline Poncho 600-FS & $96.50 \mathrm{ab}$ & $93.00 \mathrm{~b}$ & $97.00 \mathrm{a}$ & $3.50 \mathrm{a}$ & $3.00 \mathrm{a}$ & $1.00 \mathrm{ab}$ \\
\hline Gaucho 600-FS & $95.25 \mathrm{bc}$ & $92.50 \mathrm{~b}$ & $93.50 \mathrm{a}$ & $4.75 \mathrm{a}$ & $5.00 \mathrm{a}$ & $0.00 \mathrm{~b}$ \\
\hline Crusier 350-FS & $93.75 \mathrm{c}$ & $89.00 \mathrm{c}$ & $93.50 \mathrm{a}$ & $4.50 \mathrm{a}$ & $6.50 \mathrm{a}$ & $0.00 \mathrm{~b}$ \\
\hline F values & 7.88 & 20.60 & 0.464 & 8.766 & 16.957 & 3.857 \\
\hline $\mathrm{P}$ values & 0.0036 & 0.0005 & 0.712 & 0.0024 & 0.221 & 0.0383 \\
\hline
\end{tabular}

Average means. Each value with the same letter is at the same level of significance for $95 \%$ interval (Duncan's multiple comparison test $\mathrm{F}$ and $\mathrm{p}$ value)

Table 4. Shoot and root growth (mm) of seedlings of maize inbred line 7-1 NS

\begin{tabular}{|c|c|c|c|c|c|c|}
\hline \multirow{3}{*}{ Seed treatment } & \multicolumn{6}{|c|}{ INBRED LINE $7-1 \mathrm{NS}$} \\
\hline & \multicolumn{3}{|c|}{ Shoot length (mm) } & \multicolumn{3}{|c|}{ Root length (mm) } \\
\hline & $\begin{array}{c}\text { Standard } \\
\text { germination } \\
\text { test }\end{array}$ & Cold test & $\begin{array}{l}\text { Accelerated } \\
\text { ageing test }\end{array}$ & $\begin{array}{c}\text { Standard } \\
\text { germination } \\
\text { test }\end{array}$ & Cold test & $\begin{array}{l}\text { Accelerated } \\
\text { ageing test }\end{array}$ \\
\hline Control & $150.875 \mathrm{a}$ & $66.250 \mathrm{c}$ & $153.750 \mathrm{a}$ & $151.500 \mathrm{a}$ & $100.875 \mathrm{a}$ & $159.375 \mathrm{a}$ \\
\hline Poncho 600-FS & $132.875 \mathrm{~b}$ & $94.625 \mathrm{~b}$ & $37.375 \mathrm{~b}$ & $142.500 \mathrm{ab}$ & $96.125 \mathrm{a}$ & $98.750 \mathrm{~b}$ \\
\hline Gaucho 600-FS & $114.500 \mathrm{c}$ & $134.625 \mathrm{a}$ & $37.750 \mathrm{~b}$ & $115.750 \mathrm{c}$ & $85.0525 \mathrm{a}$ & $107.875 \mathrm{~b}$ \\
\hline Crusier 350-FS & $136.875 \mathrm{ab}$ & $85.500 \mathrm{~b}$ & $45.250 \mathrm{~b}$ & $125.125 \mathrm{bc}$ & $77.625 \mathrm{a}$ & $96.750 \mathrm{~b}$ \\
\hline F values & 10.169 & 44.802 & 448.378 & 4.458 & 0.5508 & 41.007 \\
\hline $\mathrm{P}$ values & 0.0013 & 0.0000 & 0.0000 & 0.0253 & 0.6572 & 0.0000 \\
\hline
\end{tabular}

Average means. Each value with the same letter is at the same level of significance for $95 \%$ interval (Duncan's multiple comparison test $\mathrm{F}$ and $\mathrm{p}$ value) 
Table 5. Germination (\%) and abnormal seedlings (\%) of maize inbred line 312/5 DNS

\begin{tabular}{|c|c|c|c|c|c|c|}
\hline \multirow[b]{3}{*}{ Seed treatment } & \multicolumn{6}{|c|}{ INBRED LINE 312/5 DNS } \\
\hline & \multicolumn{3}{|c|}{ Germination of normal seedlings ( $\%)$} & \multicolumn{3}{|c|}{ Abnormal seedlings (\%) } \\
\hline & $\begin{array}{c}\text { Standard } \\
\text { germination } \\
\text { test } \\
\end{array}$ & Cold test & $\begin{array}{l}\text { Accelerated } \\
\text { ageing test }\end{array}$ & $\begin{array}{c}\text { Standard } \\
\text { germination } \\
\text { test } \\
\end{array}$ & Cold test & $\begin{array}{l}\text { Accelerated } \\
\text { ageing test }\end{array}$ \\
\hline Control & $96.75 \mathrm{a}$ & $90.00 \mathrm{a}$ & $95.50 \mathrm{bc}$ & $1.75 \mathrm{~b}$ & $6.50 \mathrm{a}$ & $3.00 \mathrm{a}$ \\
\hline Poncho 600-FS & $95.75 \mathrm{a}$ & $89.50 \mathrm{a}$ & $93.50 \mathrm{c}$ & $4.25 \mathrm{ab}$ & $6.00 \mathrm{a}$ & $1.00 \mathrm{ab}$ \\
\hline Gaucho 600-FS & $92.25 \mathrm{~b}$ & $93.00 \mathrm{a}$ & $96.50 \mathrm{ab}$ & $5.75 \mathrm{a}$ & $5.50 \mathrm{a}$ & $1.00 \mathrm{ab}$ \\
\hline Crusier 350-FS & $97.25 \mathrm{a}$ & $93.50 \mathrm{a}$ & $98.50 \mathrm{a}$ & $2.00 \mathrm{~b}$ & $3.00 \mathrm{a}$ & $0.00 \mathrm{~b}$ \\
\hline $\mathrm{F}$ values & 9.04 & 0.775 & 6.93 & 5.102 & 0.6237 & 3.80 \\
\hline$P$ values & 0.0021 & 0.52998 & 0.0058 & 0.0167 & 0.6132 & 0.0399 \\
\hline
\end{tabular}

Average means. Each value with the same letter is at the same level of significance for 95\% interval (Duncan's multiple comparison test $\mathrm{F}$ and $\mathrm{p}$ value)

Table 6. Shoot and root growth (mm) of seedlings of maize inbred line 312/5 DNS

\begin{tabular}{ccccccc}
\hline & \multicolumn{5}{c}{ INBRED LINE 312/5 DNS } \\
\cline { 2 - 6 } Seed treatment & \multicolumn{3}{c}{ Shoot length $(\mathrm{mm})$} & \multicolumn{3}{c}{ Root length $(\mathrm{mm})$} \\
\cline { 2 - 6 } & $\begin{array}{c}\text { Standard } \\
\text { germination } \\
\text { test }\end{array}$ & Cold test & $\begin{array}{c}\text { Accelerated } \\
\text { ageing test }\end{array}$ & $\begin{array}{c}\text { Standard } \\
\text { germination } \\
\text { test }\end{array}$ & Cold test & $\begin{array}{c}\text { Accelerated } \\
\text { ageing test }\end{array}$ \\
\hline Control & $141.250 \mathrm{~b}$ & $40.000 \mathrm{c}$ & $115.125 \mathrm{a}$ & $180.625 \mathrm{a}$ & $87.750 \mathrm{~d}$ & $103.125 \mathrm{a}$ \\
Poncho 600-FS & $159.625 \mathrm{a}$ & $109.125 \mathrm{a}$ & $116.875 \mathrm{a}$ & $148.625 \mathrm{a}$ & $111.375 \mathrm{c}$ & $110.375 \mathrm{a}$ \\
Gaucho 600-FS & $144.375 \mathrm{~b}$ & $99.875 \mathrm{a}$ & $105.250 \mathrm{a}$ & $153.750 \mathrm{a}$ & $144.000 \mathrm{a}$ & $112.250 \mathrm{a}$ \\
Crusier 350-FS & $110.500 \mathrm{c}$ & $79.750 \mathrm{~b}$ & $111.375 \mathrm{a}$ & $134.625 \mathrm{a}$ & $121.000 \mathrm{~b}$ & $105.250 \mathrm{a}$ \\
\hline F values & 23.737 & 75.738 & 2.095 & 0.7006 & 71.201 & 1.923 \\
P values & 0.00003 & 0.0000 & 0.154 & 0.5696 & 0.0000 & 0.1798 \\
\hline
\end{tabular}

Average means. Each value with the same letter is at the same level of significance for $95 \%$ interval (Duncan's multiple comparison test $\mathrm{F}$ and $\mathrm{p}$ value)

treatments using the standard germination test. Also, a significant decrease in abnormal seedlings was observed in inbred line 7-1 NS treated with imidacloprid $(0.00 \%)$ and thiamethoxam $(0.00 \%)$ using the accelerated ageing test.

The obtained results showed a significant decrease in shoot and root length of inbred line 7-1 NS in all seed treatments compared to control using the standard germination test and the accelerated ageing test (Table 4). The significant increase in shoot length in all seed treatments was observed when using the cold test $(p<0.05)$, but no significant differences in root length were observed using this test $(\mathrm{p}>0.05)$.

Seed treatment with imidacloprid significantly decreased germination (92.25\%), and increased percentage of abnormal seedlings (5.75\%) compared to control in maize inbred line 312/5 DNS (Table 5). The results obtained in the cold test showed no significant differences in germination and abnormal seedlings of maize inbred line 312/5 DNS treated with the tested formulation compared to control $(\mathrm{p}>0.05)$. Seed treatment with thiamethoxam during the accelerated ageing test led to a significant decrease in the percentage of abnormal seedlings $(0.00 \%)$ compared to control.
A reduced shoot length of seedlings of inbred line $312 / 5$ DNS was observed when treated with thiamethoxam using the standard germination test, while a significantly greater length of seedlings was observed when treated with clothianidin (Table 6). A significant increase in shoot and root length of seedlings were observed in all seed treatments using the cold test $(p<0.05)$, while no significant differences were observed using the accelerated ageing test $(\mathrm{p}>0.05)$.

\section{Discussion}

The results obtained in this study showed that the effects of insecticide seed treatment on seed quality parameters depended on the varietal susceptibility of maize inbred lines. Seed treatment with imidacloprid has proven to be the most harmful, due to the fact that it caused decrease in the percentage of germination in all tested maize inbred lines using the standard germination test. It has been reported that seed germination of leek (Bi et al, 2001), white cabbage (Nault et al., 2004), rapeseed (Huang et al., 2015), and sweet maize (Schemeer et al., 1990) can be negatively affected by imidacloprid seed treatment. 
However, there are studies that point to the fact that imidacloprid does not affect seed germination of different crops, i.e. soybean (Dan et al., 2012), wheat and barley (Latheef et al., 2009), or forage brassicas (Taylor et al., 2001). Seed treatment with clothianidin also decreased germination of maize inbred line $207 \mathrm{x}$ $312 / 5$ DNS, as well as shoot and root length of seedlings during the accelerated ageing test. Cox et al. (2007) indicated no phytotoxic effects of clothianidin, considering that no negative impact on maize emergence and growth was established. High temperature and high relative humidity which the seeds are exposed to in the accelerated ageing test increase seed moisture and hydrolitic enzymes activity, which is associated with an increase in lipid peroxidation, as an indication of stressful conditions (McDonald, 1999; Vujaković et al., 2008). According to TeKrony (2001) this test provides information of seed longevity. Also, based on the obtained results it can be concluded that thiamethoxam adversely affected root length in all three tests. Negative effects of thiamethoxam and imidacloprid on seedling height were also observed (Guimarães et al., 2005; Dan et al., 2012).

Maize inbred line 7-1 NS was apparently the most sensitive to seed treatment with imidacloprid and thiamethoxam, given that these treatments reduced germination and abnormal seedlings, as well as shoot and root length of seedlings. The results related to seed treatment with imidacloprid corroborates research findings of Kuhar et al. (2002), who stated that seed treatment with imidacloprid caused a reduction in germination and increased occurence of abnormal seedlings in sweet corn. When combined with the fungicide, imidacloprid can lead to either increase or decrease of germination, depending on the genotype of maize inbred line (Tamindžić et al., 2013; Dragičević et al., 2011). Mrđa et al. (2011) also reported negative effects of imidacloprid on germination energy of sunflower seeds. With the exception of this case, the tested preparation did not generally lead to a significant increase in abnormal seedlings during vigour tests. A significant decrease in shoot and root length of seedlings was observed in all seed treatments using the accelerated ageing test.

Positive effects on viability of the seed treatment with thiamethoxam were observed in maize inbred line 312/5 DNS, since increase in germination and decrease in abnormal seedlings was noted using the accelerated ageing test. Thiamethoxam was reported to have slight positive effects on the vigour of pea, soybean and corn during germination (Horii et al., 2007; Cataneo et al., 2010). All tested formulations led to the increase in shoot and root of seedlings when using the cold test. According to McDonald (2002), the cold test was originally developed to test the efficacy of seed treatment with fungicides. Root growth is an important indicator of phytotoxicity due to high sensitivity to seed treatments. Thiamethoxam may cause changes which promote certain processes, such as growth, morphology or plant biochemistry (Almeida et al., 2013). This active ingredient showed positive effects, such as better expression of vigour during germination, biomass accumulation, high photosynthetic rate, and better penetration of roots as well asstimulation of root growth (Cataneo, 2008). Also, in the initial phase of root growth, thiamethoxam showed greater development of cortex cells and greater growth of vascular cylinder, which may favour the establishment of plants (Martins et al., 2012). According to Dragičević et al. (2011), pesticide treatment provokes decrease in hydrolysis and simultaneous increase in biosynthesis.

\section{Conclusion}

Results of testing seed physiological quality parameters of maize inbred lines treated with neonicotinoids, which were obtained by the standard germination test, indicate varietal specificity of inbred lines. The use of vigour tests also provided an estimation of comparative seed storage potential of maize inbred lines when different lots representing each genotype are evaluated. Imidacloprid has proven to be the most aggressive of all the active components tested. Considering that maize inbred lines are more sensitive to biotic and abiotic stresses than maize hybrids, such study enables us to consider all aspects of protection against attacks by pests, and provides better insight into seed viability and vigour. This study also confirmed that vigour tests provide guidance regarding seed treatment with insecticides. It can also be concluded that adequate seed treatment depends on the genotype.

\section{References}

Abba, E. J., \& Lovato, A. (1999). Effect of seed storage temperature and relative humidity on maize (Zea mays L.) seed viability and vigour. Seed Sci. Technol., 27, 101-114.

Almeida, A. S., Villela, F. A., Nunes, J. C., Meneghello, G. E., \& Jauer, A. (2013). Thiamethoxam: An Insecticide that improve seed rice germination at low temperature in insecticides. In: S. Trdan (Ed.), Development of Safer and More Effective Technologies, pp. 417-426. doi: $10.5772 / 53207$

Aveling, T. A. S., Govender, V., Kandolo, D. S., \& Kritzinger, Q. (2012). The effects of treatments with selected pesticides on viability and vigour of maize (Zea mays L.) seeds and seedling emergence in the presence of Fusarium graminearum. J Agric Sci., 4, 1-8. doi: $10.1017 / \mathrm{s} 0021859612000457$

Bi, J. L., Ballmer, G. R., Hendrix, D. L., Henneberry, T. J., \& Toscano, N. C. (2001). Effect of cotton nitrogen fertilization on Bemisia agrentifolii populations and honeydew production. Entomol Exp Appl, 99, 25-36.

Castro, G. S. A., Bogiani, J. C., Silva, M. G., Gazola, E., \& Rosolem, C. A. (2008). Tratamento de sementes de soja cominseticidas e um biostimulante. Pesq Agropec Bras. 43, 1311-1318.

Castro, P. R. C., Serciloto, C. M., Pereira, M. A., Rodrigues, J. L. M., \& Rossi, G. (2009). Agroquimicos de controle hormonal, fosfitos $e$ potencial de aplicaçăo de aminoácidos na agricultura tropical. Piracicaba: DIBD/ESALQ/USP, Série Produtor Rural.

Cataneo, A. C. (2008). Ação do Tiametoxam sobre a germinação de sementes se soja (Glycine max L.): Enzimas envolvidas na mobilização de reservas e na proteção contra situaçã de estresse (deficiência hidrica, salinidade e presença de aluminio). In: D. L. Gazzoni (Ed.), Tiametoxam: uma revolução na agricultura brasileira (pp. 123-192). Petropolis: Vozes.

Cataneo, A. C., Ferreira, L. C., Carvalho, J. C., Andréo-Souza, Y., Corniani, N., Mischan, M. M., \& Nunes, J. C. (2010). Improved germination of soybean seed treated with thiamethoxam under drought conditions. Seed Sci Techn., 38, 248-251.

Cox, W. J., Shields, E., \& Cherney, J. H. (2007). The effects of clothianidin seed treatments on corn growth following soybean. Crop Sci., 47, 2482-2485. 
Dan, L. G. M., Dan, H. A., Braccini, A. L., Barrosp, A. L. L., Ricci, T. T., Piccinin, G. G., \& Scapim, C. A. (2012). Insecticide treatment and physiological quality of seeds. In: P. Farzana (Ed.), Insecticides Advances in integrated pest management, doi: 10.5772/29102

Dragičević, V., Gošić-Dondo, S., Jug, I., Srdić, J., Sredojević, S. (2011) The influence of seed treatments on germination and initial growth of maize seedlings. Proceedings of the $46^{\text {th }}$ Croatian and $6^{\text {th }}$ International Symposium on Agriculture, Opatia, pp. 654-657.

Guimarães, R. N., Porto, T. B., Barbosa, L. A., Fernandes, P. M., Costa, R. B., \& Barros, R. G. (2005). Efeito do tratamento de sementes com inseticidas na emergência altura de plântulas de feijão. In: Congresso Nacional de Pesquisa de Feijão, Goiânia, 8, 94-99 (Documentos, 182).

Hampton, J. G., \& TeKrony, D. M. (1995). Handbook of vigour test methods. Zurich: International Seed Testing Association.

Horii, A., McCue, P., Shetty, K. (2007). Enhancement of seed vigour following insecticide and phenolic elicitor treatment. Bioresour Technol. 98, 623-632.

Huang, L., Zhao, C., Huang, F., Bai, R., Lu, Y., Yan, F., \& Hao, Z. (2015). Effects of imidacloprid and thiamethoxam as seed treatments on the early seedling characteristics and aphid-resistance of oilseed rape. $J$ Integr Agr, 14(12), 2581-2589.

ISTA (2014). International Rules for Seed Testing. Bassersdorf, Switzerland, International Seed Testing Association.

Koch, R. L., Burkness, E. C., Hutchison, W. D., \& Rabaey, T. L. (2005). Efficacy of systemic insecticide seed treatments for protection of early-growth-stage snap beans from bean leaf beetle (Coleoptera: Chrysomelidae) foliar feeding. Crop Prot. 24, 734-742.

Kuhar, T. P., Stivers-Young, L. J., Hoffman, M. P., \& Taylor, A. G. (2002). Control of corn flea beetle and Stewart's wilt in sweet corn with imidacloprid and thiamethoxam seed treatments. Crop Prot. 21, 25-31.

Latheef, M. A., Carlton, J. B., Kirk, I. W., \& Hoffmann, W. C. (2009). Aerial electro static charged sprays for deposition and efficacy against sweet potato whitefly (Bemisia tabaci) on cotton. Pest Manag Sci, 65, 744-752.

Marjanović-Jeromela, A., Marinković, D., Milovac, Ż., Miladinović, D., Sekulić, R., \& Jasnić, S. (2008): Testiranje sjemenskih kvaliteta sjemena uljane repice (Brassica napus L.) tretiranog insekticidima i fungicidima. Glasnik qaśtite bilja, 4, 13-21.

Martins, R. G., Martins, M. B. G., Silva, J. M., Pereira, M. A., Gloria, B. A., \& Castro, P. R. C. (2012). Thiamethoxam on the histological characteristics of sugarcane young roots. Ciência Rural. 42(1), 19361940.

McDonald, M. B. (1999). Seed deterioration: physiology, repair and assessment. Seed Sci Technol. 27, 177-237.

McDonald, M. B. (2002). Standardization of seed vigor tests. Proceedings International Seed Seminar: Trade, Production and Technology. Chile, pp. 200 -208 .
Milošević, M., Vujaković, M., \& Karagić, Đ. (2010). Vigour tests as indicators of seed viability. Genetika, 42(1), 103-118.

Mrđa, J., Crnobarac, J., Dušanić, N., Jocić, S., \& Miklič, V. (2011) Germination energy as parameter of seed quality in different sunflower genotypes. Genetika, 43(3), 427-436.

Nault, B. A., Taylor, A. G., Urwiler, M., Rabaey, T., \& Hutchison, W. D. (2004). Neonicotinoid seed treatments for managing potato leafhopper infestations in snap bean. Crop Prot. 23, 147-154.

Schemeer, H. E., Bluett, D. J., Meredith, R., \& Heatherington, P. J. (1990). Field evaluation of imidacloprid as an insecticidal seed treatment in sugar beet and cereals with particular reference to virus vector control. In: Proceedings of Brighton Crop Protection Conference, Pest and Disease. BCPC, Alton, Hants, UK, pp. 29-36.

Sekulić, R., Kereši, T., \& Radonjić, K. (2005). Some economically important pests of sugar beet and corn-condition, prognosis and potential control. Zbornik radova Instituta za ratarstvo i pourtarstvo Novi Sad, 41, 521-531.

Stevens, M. M., Reinke, R. F., Coombes, N. E., Helliwell, S., \& Mo, J. (2008). Influence of imidacloprid treatments on rice germination and early seedling growth. Pest Manag Sci. 64, 215-222.

Tamindžić, G., Nikolić, Z., Popov, R., Jovičić, D., Zdjelar, G., Župunski, V., \& Ignjatov, M. (2013). Effect of seed treatments with neonicotinoids on maize inbred lines seed quality. Ratar Porrt. 50(3), $37-44$.

Taylor, A. G., Eckenrode, C. J., \& Straub, R. W. (2001). Seed coating technologies and treatments for onion: Challenges and progress. HortScience, 36, 199-205.

TeKrony, D. M. (2001). Seed Vigor Testing. In: M B McDonald, T Gutormson and B Turnipseed (Eds.), Seed Technology Training Manual. Society of Commercial Seed Technologists, Ithaca, NY, pp.11-20

Tomizawa, M., Casida, J. E. (2011). Neonicotinoid insecticides: Highlights of a symposium on strategic molecular design. J. Agric. Food Chem. 59 (7), 2883-2886.

Vujaković, M., Milošević, M., Nikolić, Z., Taški-Ajduković, K., Miladinović, J., Ignjatov, M., \& Dokić, V. (2008). Seed vigour in soybean production with and without irrigation. PTEP 12(1-2), 19-21.

Vujaković, M., Jovičić, D., Karagić, Đ., Mikić, A., Petrović, D., \& TaškiAjduković, K. (2011a). Pokazatelji životne sposobnosti semena ozimih grahorica Vicia spp.). Ratar. Povrt. 48, 131-136.

Vujaković, M., Balešević-Tubić, S., Jovičić, D., Taški-Ajduković, K., Petrović, D., Nikolić, Z., \& Đorđević, V. (2011b). Viability of soybean seed produced under different agro-meteorological conditions in Vojvodina. Genetika, 43(3), 625-638.

\section{Životna sposobnost i vigor semena različitih inbred linija kukuruza tretiranih neonikotinoidima}

\section{Gordana Tamindžić · Zorica Nikolić · Dragana Milošević · Maja Ignjatov}

Sažetak: Cilj ovog istraživanja je bio da se ispita uticaj različitih tretmana semena neonikotinoidima na životnu sposobnost i vigor semena inbred (Zea mays L.) linija kukuruza. Eksperimentalni objekti su bile tri različite inbred linije kukuruza (207 x 312/5 DNS, 7-1 NS i 312/5 DNS) tretirane sa tri komercijalne formulacije (Poncho 600-FS, Gaucho 600-FS i Cruiser 350-FS) u preporučenim dozama. Generalno se Gaucho 600-FS može smatrati štetnim pošto utiče na smanjenje klijavosti semena kod svih ispitivanih inbred linija. Značajno smanjenje klijavosti semena inbred linije 7-1 NS primećeno je nakon tretmana sa Cruiser 350-FS kod standarnog testa klijavosti i hladnog testa. Značajan porast korena i nadzemnog dela izdanaka inbred linije 312/5 DNS tretirane formulacijama Poncho 600-FS i Cruiser 350-FS je uočen primenom hladnog testa.

Ključne reči: inbred linije kukuruza, kukuruz, neonikotinoidi, životna sposobnost, vigor, standardni test klijavosti, hladni test 